\title{
Hepatit B prevalansı ve aile içi bulaşım yolları
}

\author{
Prevalence and interfamily transmission pathways of hepatitis B virus
}

\author{
Bilge BAŞ \\ Yakın Doğu Üniversitesi, Gastroenteroloji Bölümü, Lefkoşa, Kıbrıs
}

\begin{abstract}
Giriş ve Amaç: Hepatit B bulaştırıılığı, yaygınlığı ve önlenebilirliği nedeniyle önemli bir halk sağlığı sorunudur. Kan ve seröz eksudalarda yoğunken tükürük, semen ve vajinal sekresyonlarda düşüktür. Bu nedenle günlük yaşam koşulları ile bulaş olmaz kabul edilir. Amacımız; HBsAg pozitif olgularda, toplu yaşam koşulları, sosyo kültürel alışkanlıklara göre, aile içi bulaş yollarını ve yaygınlığını incelemektir. Materyal ve Metod: Çalışmamızda inaktif HBsAg taşıyıIIsı ve kronik hepatit B tanısı alan olgular ve birinci derecede yakınları hepatit $B$ göstergeleri yönünden araştırıldı. Meslek, eğitim, diş tedavisi, kan transfüzyonu, geçirilmiş operasyon, doğum şekli, aynı eşyaları kullanma ve yakınlık dereceleri sorgulandı. Bulgular: 820 hastanın \%61.7'si erkek, \%38.3'ü kadın ve \%48.9'u 40 yaşın altında idi. illk ve orta öğrenim eğitimi olanlar \%37.4 ve \%37.9 ile çoğunluğu oluşturmaktadır. Hastaların \%61.5'i kentsel, \%38.5'i kırsal kökenli ve yaklaşık dörtte birinin evinde 6 ve üzeri kişi yaşamaktadır. Tahmini bulaş yolları arasında diş tedavisi (\%68.3) ilk sıradadır. Bunu hastanede yatış (\%34.4), cerrahi girişim (\%32.9), kan transfüzyonu (\%19.3) ve \%2.2 ile şüpheli ilişki izlemektedir. Hastaların aile üyelerinde hepatit B varlığına bakıldığında \%44.1 ile ilk sırayı anneler almaktadır. Ortak eşya kullanımı değerlendirildiğinde \%83.2 ile aynı havluyu kullanma ilk sıradadır. Bunu aynı tıraş bıçağını ve tırnak makasını kullanma izlemektedir. Ortak diş fırçası kullanımı yoktur. Sonuç: HBsAg pozitifliği erkeklerde ve kırsal kesimde daha fazladır. Diş tedavisi, cerrahi girişim, hastaneye yatışın HBsAg pozitifliğine etkisi vardır. Aile içi bulaş oranı fazladır ancak bulaş ortak eşya kullanımına bağıdır denilemez. Ailede hepatit B varlığı aile bireylerinde HBsAg pozitifliğini artırmaktadır. Bundan dolayı bir bireyde HBsAg pozitifliği mevcutsa diğer aile bireylerinin aşılanması sağlanmalıdır.
\end{abstract}

Anahtar kelimeler: Hepatit B, bulaş, aile, diş tedavisi, kan nakli

\section{GíRiş}

Dünyada 2 milyara yaklaşan sayıda kişinin ömrünün bir döneminde hepatit B virüsü (HBV) ile karşılaşmış olduğu ve bunların 400 milyona yakınının kronik HBV enfeksiyonu olgusu olduğu bilinmektedir (1). Bir yıl içinde yaklaşık 1 milyon kişinin HBV ile ilişkili hastalıklar nedeniyle kaybedildiği düşünülmektedir. Dünya sağlık örgütü (DSÖ) tarafından yapılan, 1980-2007 arasındaki süreci inceleyen metaanalizde 1990-2005 yıllarına bakıldığında dünya ge-

İletişim: Bilge BAŞ

Yakın Doğu Üniversitesi, Gastroenteroloji Bölümü, Lefkoşa, Kıbrıs

E-mail: bilgeormeci@hotmail.com
Background and Aims: Hepatitis $B$ is an important public health problem due to its transmittance, prevalence, and preventability. It is present at higher concentrations in blood than in saliva, semen, and vaginal secretions. In practice, infection is not transmitted under daily living conditions. Our purpose is to examine intrafamilial transmission and prevalence in HbsAg-positive cases and their families. Materials and Methods: HBsAg carriers, chronic Hepatitis B-infected patients, and their relatives were examined for hepatitis $B$ indicators. Study participants were questioned about educational status, dental treatment, blood transfusions, operations, and type of birth. Results: Of the 820 patients in our study, 506 were male and 314 were female. Approximately half of the patients were under 40 years of age. Patients with primary and secondary education represented $37.4 \%$ and $37.9 \%$ of the sample, respectively. The estimated pathways of infection were as follows: dental treatment, 68.3\%; hospital stay, 34.4\%; surgical intervention, 32.9\%; blood transfusion, 19.3\%; and suspicious relationship, $2.2 \%$. When hepatitis $B$ was present in family members, mothers were the most frequently infected, representing $44.1 \%$. Conclusion: In our study, HBsAg positivity was more common in men than in women and more common in the countryside than in urban areas. Risk factors such as dental treatment, surgical intervention, and hospitalization have an effect on HBsAg positivity. The rate of infection increases with intrafamilial usage of shared objects, but it cannot be stated that infection is completely based on shared object usage. The presence of hepatitis $B$ within the family increases HBsAg positivity in other family members. Accordingly, when HBsAg positivity is present in a member of the family, other family members should be vaccinated.

Key words: Hepatitis B, blood transfusion, family, odontotherapy, transmittance

nelinde kronik HBV enfeksiyonunun azaldığı görülmüştür (2). Hepatit B yüzey antijeni (HBsAg) pozitifliğinin dünya genelinde en yüksek prevalansının Afrika bölgesi olduğu düşünülmektedir, ancak vakaların birçoğu sessiz klinik nedeniyle bu durumlarının farkında değildir. Dünya genelinde uygulanmakta olan aşılama programları ile HBV enfeksiyonunda anlamlı azalma vardır. Buna rağmen yeni hepatit B enfeksiyonu olan hastalar görülmektedir. 
Bunun nedeni de HBV'nin nasıl bulaştığının yeterince bilinmemesi, aile aşılanmasının efektif yapılamaması ve enfeksiyona sahip bireylerin bunun farkında olmamasıdır. HBV'ye karşı bağışık olmayan bir bireyin, enfeksiyon kaynağı ile teması, deri veya mukoz membranlarında açık yara ile hastalığın bulaşına zemin hazırlanır. HBV tüm vücut sıvılarında bulunur ve bunlarla temasla bulaşabilir. Kan ve seröz sıvılarda en yüksek oranda bulunurken; tükürük, vajinal sıvı ve semende daha az oranlarda bulunur. Tüm bu koşulların günlük yaşamda ve ev ortamında birarada olmasının güçlüğü nedeniyle bu şekilde bulaş olmadığı kabul edilmektedir. Ancak direkt yaralanma ve kan teması olan ortak enjektör kullanımı, diyaliz, dövme, manikür vb. bulaşma için risk faktörleridir. Bizim ülkemiz gibi endemik ülkelerde doğumda anneden bebeğe geçiş yaygındır (3). Horizantal geçişin nedeni tam olarak bilinmese de aynı evde yaşama ve aynı eşyalara temastan şüphenilmektedir. Cinsel yolla geçiş en sık bulaşma şekillerindendir. Kan ürünlerinin son yıllarda sıkı incelenmesi sonucu kan trasfüzyonu ile geçiş azalmışıı ancak hastanede yapılan herhangi bir müdahale esnasında bulaş halen söz konusudur. Kan ürünlerinde HBsAg taraması 1970 yılı sonlarında başlamıştır ve hastalığın azalmasında önemli bir role sahiptir, ancak tüm ileri yöntemlere rağmen risk her zaman var kabul edilir (4). Hepatit B early antijen (HBeAg)'nin plesantayı geçmesi nedeniyle doğum sırasında kadınlarda bu antijenin pozitif olması halinde perinatal enfeksiyon oluşma ihtimali yükselir (5). Ülkemizde HBsAg prevalansı ile ilgili yapılan 129 çalışmanın dahil edildiği bir metaanaliz sonucu toplumda HBsAg pozitifliği \%4.57 yani 3.3 milyon kişidir (6). Bizim çalışmamızda amacımız HBV pozitif olgularda, toplu yaşam koşulları, sosyokültürel alışkanlıkları göz önüne alınarak, aile içi ve diğer bulaş yollarını ve yaygınlığını incelemektir.

\section{GEREÇ ve YÖNTEM}

\section{Çalışma Dizaynı}

Tek merkezli, tanımlayıcı klinik bir çalışma olup, tek bir gastroenteroloji hekimi tarafından kayıtlı hepatit B hastalarına yüzyüze ve telefonla anket yapılmışır. Anket formu cinsiyet, yaş, meslek, eğitim durumu, diş tedavisi, kan transfüzyonu, ameliyat olup olmama durumu, doğum şekli, aynı havlu, aynı diş fırçası, aynı tıraş bıçağı ve tırnak makasını kullanıp kullanmama, hepatitli kişiye yakınlık derecesi ve ailede ilk hepatit B tanısı alan bireyleri sorgulayan sorulardan oluşmaktadır. Çalışmamı için yetkili hastaneden etik kurul onamı alınmıştır ve Helsinki Deklerasyonu Prensipleri'ne uygunluk ilkesini kabul katılmış insanlardan "Bilgilendirilmiş olur" alınmıştır.

\section{Hasta Grubu ve Yöntem}

Çalışmamızda Hepatit B polikliniği tarafından takip edilen, inaktif HBsAg taşıyıcısı ve kronik hepatit tanısı alan toplam 820 olgu ve bu olguların birinci derecedeki aile bireylerinin tümü hepatit $\mathrm{B}$ göstergeleri yönünden araştıııldı.

Hastaların HBsAg, hepatit B yüzey antikoru (anti-HBs), Hbe-Ag, hepatit B early antikoru (anti-HBe), total hepatit B core antikoru (anti-HBc) ve HBV-DNA testleri çalışıldı. Beraberinde insan bağışıklık yetmezlik virüsü (HIV), anti hepatit $C$ virüsü $(H C V)$, anti hepatit Delta virüsü (HDV) pozitifliğine bakıldı; pozitif olan olgular çalışmaya dahil edilmedi. HBsAg, anti-HBs, HbeAg, anti-HBe ve total anti-HBc belirteçleri hastanemiz mikrobiyoloji laboratuvarında Abbott AxSYM kiti ve Abbott Macro Eliza (made by Abbott) cihazı ile çalışıldı. HBV-DNA ise Cobas TaqMan HBV test kiti ile Real-Time PCR tekniği kullanılarak Cobas TaqMan 48 (made by Roche Molecular Systems, Inc.) cihazında çalışıımıştır.

Araştırmaya inaktif HBsAg taşıyıcısı (HBsAg ve anti-HBC total pozitif, karaciğer enzimleri normal HBV-DNA< $10^{4}$ ) ve birinci derece yakınları ile kronik HBV hastaları ( $\mathrm{HbsAg}$, HBV-DNA> $10^{4} \mathrm{kopya} / \mathrm{ml}$, antiviral tedavi almakta olan) ve birinci derece yakınları dahil edildi.

\section{Bağımsız Değişkenlerin Değerlendirilmesi}

Yaş: Doğum tarihlerinden hesaplandı. 20-39, 40-59, 60 yaş ve üzeri olmak üzere üç grupta sunuldu.

Cinsiyet: Kadın ve erkek olarak değerlendirildi.

Eğitim durumu: Son bitirilen okul göz önüne alınarak; okuryazar değil, okuryazar ya da ilkokul mezunu, ortaokul-lise mezunu ve yüksekokul mezunu olarak dört grupta incelendi.

\section{Bağımlı Değişkenlerin Değerlendirilmesi}

HBsAg testi: ELISA yöntemi ile çalışıldı. Sonuçlar pozitif ve negatif olarak değerlendirildi. (Cut off değeri: $1 \mathrm{IU} / \mathrm{ml}$ )

Anti-HBc testi: ELISA yöntemi ile çalışıldı. Sonuçlar pozitif ve negatif olarak değerlendirildi. (Cut off değeri: $1 \mathrm{lU} / \mathrm{ml}$ )

Anti-HBs testi: ELISA yöntemi ile çalışıldı. Sonuçlar pozitif ve negatif olarak değerlendirildi. (Cut off değeri: $7 \mathrm{IU} / \mathrm{ml}$ )

\section{İstatistiksel Analiz}

Araştırmada elde edilen veriler SPSS for Windows 10.0 paket programına aktarıldı. Ortalama değerler "aritmetik ortalama standart sapma" olarak hesaplandı. Gruplar arası değerlendirmede ki-kare testi kullanıldı. Analiz sonuçları \%95 güven aralığında değerlendirildi. İstatistiksel anlamlıık düzeyi $p<0.05$ olarak kabul edildi. 
Tablo 1. Hastaların demografik dağılımı

\begin{tabular}{|c|c|c|c|c|c|c|}
\hline \multirow[b]{2}{*}{ Yaş } & \multicolumn{2}{|c|}{ Erkek } & \multicolumn{2}{|c|}{ Kadın } & \multicolumn{2}{|c|}{ Toplam } \\
\hline & $\mathrm{n}$ & $\%$ & $\mathrm{n}$ & $\%$ & $\mathbf{n}$ & $\%$ \\
\hline 20- 39 & 301 & 59.5 & 100 & 31.8 & 401 & 48. 9 \\
\hline 40- 59 & 132 & 26. 1 & 170 & 54. 1 & 302 & 36.8 \\
\hline$\geq 60$ & 73 & 14. 4 & 44 & 14.0 & 117 & 14. 3 \\
\hline Total & 506 & 100 & 314 & 100 & 820 & 100 \\
\hline
\end{tabular}

\section{BULGULAR}

Çalışmamıza Hepatit B polikliniğinde takip edilen 820 hasta alındı. Hastaların yarıya yakını $(n=401 ; \% 48.9) 40$ yaşın altında ve \%14.3'ü ise 60 yaş ve üzerindedir. Hastaların \%61.7'si erkek, \%38.3'ü ise kadındır ( $p=0.02$ ) (Tablo 1). Eğitim durumuna göre dağıımı değerlendirildiğinde ilkokul ve orta öğrenim düzeyinde eğitimi olanların \%37.4 ve \%37.9 ile çoğunluğu oluşturduğu görülmektedir ve hastaların \%61.5'i kentsel, \%38.5'i ise kırsal kökenlidir. Çalışmaya alınan hastaların evde yaşayan kişi sayısına göre dağııımı değerlendirildiğinde hastaların yaklaşık dörtte birinin evinde 6 veya daha fazla kişinin yaşadığı görülmektedir. Çalışmaya alınan hastaların yarısının doğumunun evde diplomalı ebe ile gerçekleştiği görülmektedir. Çalışmaya alınan hastalarda tahmini viral bulaş şekline ilişkin anamnezleri sorgulanmıştır. Hastaların \%10.1'inde anamnezde özellik saptanmamışı̧ı. Tahmini bulaş yolları arasında \%68.3 ile ilk sırada diş tedavisi öyküsü yer almaktadır. Bunu \%34.4 ile hastanede yatış, \%32.9 ile cerrahi girişim, \%19.3 ile kan transfüzyonu ve \%2.2 ile şüpheli ilişki izlemektedir. Çalışmaya alınan hastalar evde ortak eşya kullanımı açısından değerlendirildiğinde \%83.2 ile aynı havluyu kullanma ilk sırada yer almakta, bunu \%79.3 ile aynı tıraş bıçağını ve/veya tırnak makasını kullanma ve \%69.8 ile aynı mutfak eşyasını kullanma izlemektedir. Çalışmaya alınan hastalar içinde evde diş fırçasını aile üyeleriyle paylaşan yoktur (Tablo 2). Çalışmaya alınan hastalarda aile üyelerinde hepatit B varıı̆ı sorgulanmıştır. Hepatitli aile üyeleri arasında ilk sırada anneler yer almaktadır. Annelerinde hepatit olan hastaların dörtte birinde birlikte kardeşlerden en az birinde de hepatit mevcuttur. Kardeşlerinde hepatit olan hastaların büyük çoğunluğunda birlikte annelerinde de hepatit mevcuttur. Hastaların 184'ünde (\%22.4) eşinde ve 164'ünde (\%20.0) en az bir çocuğunda hepatit vardır (Tablo 3).

\section{TARTIŞMA}

HBV enfeksiyonun dağıımı coğrafi bölgelere göre farklılıklar gösterir. Dünya; düşük, orta ve yüksek endemik bölgelere ayrımıştır. Sınıflandırmada; bölgedeki HBsAg ve anti-HBs pozitifliği oranları, enfeksiyonun alınma yaşı

\begin{tabular}{|c|c|c|}
\hline Eğitim seviyesi & $\mathbf{n}$ & $\%$ \\
\hline Okuma yazma yok & 92 & 11.2 \\
\hline Ilkokul & 307 & 37.4 \\
\hline Ortaokul & 311 & 37.9 \\
\hline Lise & 110 & 13.4 \\
\hline \multicolumn{3}{|l|}{ Yaşam yeri } \\
\hline Kent & 504 & 61.5 \\
\hline Kırsal & 316 & 38.5 \\
\hline \multicolumn{3}{|l|}{ Aile birey sayısı } \\
\hline $1-3$ & 374 & 45.6 \\
\hline 4- 5 & 264 & 32.2 \\
\hline$\geq 6$ & 182 & 22.2 \\
\hline \multicolumn{3}{|l|}{ Olası bulaş yolu } \\
\hline Diş tedavisi & 560 & 68.3 \\
\hline Hastanede yatış & 282 & 34.4 \\
\hline Cerrahi müdahale & 270 & 32.9 \\
\hline Kan nakli & 158 & 19.3 \\
\hline Şüpheli ilişki & 18 & 2.2 \\
\hline Bilinmeyen & 83 & 10.1 \\
\hline Ortak obje kullanımı & n & $\%$ \\
\hline Havlu & 682 & 83.2 \\
\hline Tıraş bıçağı & 650 & 79.3 \\
\hline Bardak ve tabak & 572 & 69.8 \\
\hline Diş fırçası & 0 & 0 \\
\hline
\end{tabular}

Tablo 3. Aile bireylerindeki hepatit B varlığı

\begin{tabular}{|lcc|}
\hline Hepaptit B'li aile bireyi & $\mathbf{n}$ & $\%$ \\
\hline Anne & 362 & 44.1 \\
\hline Eş & 184 & 22.4 \\
\hline Baba & 182 & 22.2 \\
\hline En az bir çocuk & 164 & 20 \\
\hline En az bir kardeş & 112 & 13.7 \\
\hline Anne ve kardeş & 87 & 10.6 \\
\hline Eş ve çocuk & 24 & 2.9 \\
\hline Baba ve kardeş & 12 & 1.5 \\
\hline Anne ve baba & 11 & 1.3 \\
\hline
\end{tabular}


ve virusun en sık hangi yolla bulaştığı göz önünde bulundurulmuştur. HBsAg pozitifliği Dünya genelinde $\% 5.8$ oranındadır ve yılda 500 bin ile 700 bin kişinin ölümüne neden olmaktadır. Afrika bölgesi dünyada HBsAg prevalansının en yüksek olduğu bölge olarak düşünülmektedir ve vaka sayısı ortalama \%5-8 arasında bir orana sahiptir. Avustralya, Japonya ve Yeni Zelanda \%2'den daha az görülme oranı ile en düşük HBsAg pozitifliğine sahip ülkelerdir. Parenteral enjeksiyon, kan ve kan ürünleri transfüzyonu daha sık olmasına rağmen batılı toplumlarda HBV seropozitifliğinin düşük olmasının sebebi konuya gereken önemin verilmesi ve alınan tedbirlerin ciddi bir şekilde uygulanmasıdır. Ancak HBV dünya genelinde hala önemli bir sorundur.

Ülkemizde 1999-2009 yılları arasında HBsAg prevalansı ile ilgili yapılan 129 çalışmanın dahil edildiği bir metaanaliz sonucu toplumda HBsAg pozitifliği \%4.57 yani 3.3 milyon kişidir. Bu değerler göz önüne alındığında ülkemiz orta endemik bölgeler arasında yer almaktadır. Batı bölgelerinde oran \%3.47 (1.055.908 kişi), iç Anadolu'da \%4.86 (1.366.314 kişi), Doğu ve Güneydoğu Anadolu'da \%6.72 (871.854 kişi) olarak bulunmuştur. Demirpençe (7) ve arkadaşlarının yaptığı Batman ilindeki çalışmada HBsAg pozitifliği \%12.6 olarak tespit edilmiştir. Ülkemizde özellikle Doğu ve Güneydoğu Anadolu bölgelerinde parenteral bulaşdan ziyade daha çok vertikal ve aile içi bulaş önemli gözükmektedir.

Çalışmamızda 820 hastanın \%61.7'si erkek, \%38.3'ü ise kadındır. HBsAg pozitifliğinin erkeklerde daha sık olduğu ve cinsiyetler arasındaki bu farkın istatistiksel olarak anlamlı olduğu görülmektedir ( $p=0.02$ ). Bizim sonuçlarımizla uyumlu olarak ulusal literatürde HBV enfeksiyonu seroprevalansının erkeklerde daha yüksek olduğu ifade edilmektedir. Ancak DSÖ'nün gerçekleştirdiği metaanalizde cinsiyete göre HBsAg prevalansına bakıldığında kadınlarda \%3.5 ve erkeklerde \%3.9 oranılla anlamlı bir fark bulunmamıştır. 2009 yılı TÜiK verilerine göre hesaplanan 20 yaş üzeri Türkiye nüfusunun cinsiyet dağılımı ile karşılaştıııldı̆ında erkek hasta oranııın beklenenden daha fazla, kadın hasta oranının da beklenenden daha az olduğu görülmektedir. Türkiye genelinde erkeklerin tüm nüfusa oranı \%50.2 iken hepatit B'li hastalarda bu oran $\% 61.7$ 'dir. Buna dayanarak erkeklerde hepatit B riskinin kadınlara göre 1.60 kat daha yüksek olduğu söylenebilir. Risk faktörleri ile daha sık karşılaşıyor olmaları HBsAg pozitifliğinin erkeklerde daha sık görülmesinin bir nedeni olabilir. 2008-2011 yılları arasında gerçekleştirilen TÜRKHEP ÇALIŞMASI ile tüm Türkiye'de 23 ayrı bölgede HBsAg pozitifliği değerlendirilmiş ve oranın yaşla artış gösterdiği belirlenmiştir. 18-29 yaş arası \%2.7, 30-39 yaş arası \%3.9,
40-49 yaş arası \%4.6, 50-59 yaş arası \%5.3, 60-69 yaş arası \%4.4, 70 yaş ve üstü \%4.4 olarak rapor edilmiştir (8). Bizim çalışmamızda yaş gruplarındaki HBsAg seropozitifliği karşılaştııılıı̆ında, çalışmaya alınan hastanın yarıya yakını ( $n=401 ; \% 48.9) 40$ yaşın altındadır ve diğer gruplara göre anlamlı olarak yüksek orandadır $(p<0.05)$. Tüm grubun \%36.8'i 40-59 yaşları arasında, \%14.3'ü ise 60 yaş ve üzerindedir. Yaş arttıkça hasta yoğunluğu azalmaktadır. Bu durum hastaneye başvuruların ya da hepatit yönünden taramaların (evlilik öncesi, gebelik vb.) daha genç yaşta olması ile ilgili olabilir.

Araştırmamızda HBsAg pozitifliğinin kırsal alanda daha sık olduğu görüldü. Türkiye genelinde kırsal kökenlilerin tüm nüfusa oranı \%29.0 iken hepatit B'li hastalarda bu oran \%38.5'tir. Buna dayanarak kırsal kökenlilerde hepatit B riskinin kent kökenlilere göre 1.53 kat daha yüksek olduğu söylenebilir ve bu da anlamlı bir yüksekliktir ( $p<$ 0.05). Literatürde HBsAg pozitifliği açısından kırsal ve kentsel kesim arasında fark olmadığını belirten yayınlar vardır (9). Buna karşın Dursun ve arkadaşları (10) kırsal kesimde HBsAg pozitifliğinin kentsel kesime göre anlamlı oranda yüksek olduğunu, yaşla beraber HBV ile karşılaşma oranının arttığını belirmişlerdir.

Yapılan literatür taramasında HBsAg seropozitifliğinin kişilerin eğitim düzeyleri ve anne eğitim düzeyleriyle ilişkisini araştıran çalışmalara ulaşılamamıştır. Çalışmaya alınan hastaların eğitim durumuna göre dağııımı değerlendirildiğinde ilkokul ve orta öğrenim düzeyinde eğitimi olanların \%37.4 ve \%37.9 ile çoğunluğu oluşturduğu görülmektedir $(p=0.02)$. Eğitim düzeyi düşük bireylerin bilinçlilik, korunma, aşılanma oranlarının düşük ve aile ortamlarının kalabalık olduğu varsayılarak bu durum açıklanabilir.

Çalışmaya alınan hastaların evde yaşayan kişi sayısına göre dağılımı değerlendirildiğinde hastaların yaklaşık dörtte birinin $(\% 22,2)$ evinde 6 veya daha fazla kişinin yaşadığı görülmektedir. Yarıya yakınında $(\% 45,6)$ ise evde yaşayan kişi sayısı 3'le sınırıdır. Kalabalık ailenin beklenenden daha az olması büyük şehirlerde çekirdek ailelerin gittikçe yaygınlaşmasından kaynaklanabilir.

Amerika Birleşik Devletleri'nde HBV bulaşı sıklıkla damar içi iğne kullanımı ve cinsel yolla olmaktadır (11). Centers for Disease Control and Prevention (CDC) verilerine göre akut hepatit B olgularının yarıdan fazlasında $(\% 55,6)$ bulaş yolu ortaya konulamamıştır. Bu çalışmada bildiğimiz risk faktörleri sorgulandığında şüpheli cinsel ilişki $(\% 33,4)$, damar içi madde bağımlıı̆̆ı (\%16.1), homoseksüel ilişki $(\% 14,6)$, cerrahi öyküsü $(\% 10,2)$, HBV ile enfekte kişi ile cinsel temas $(\% 7,7)$, perkütan yaralanma $(\% 4,7)$, HBV'li kişi ile aile içi temas $(\% 1,3)$, kan trasfüzyonu $(\% 0,6)$, 
sağlık çalışanı teması $(\% 0,5)$ ve hemodiyaliz $(\% 0,2)$ olarak bildirilmiştir (12). Bizim çalışmamızda ülkemizin sosyokültürel özellikleriyle ilgili olarak bu değerler oldukça farklıdır. Eşcinsel ve şüpheli ilişki, madde bağımlılığı yok denecek kadar azdır. Bizim hastalarımızın kronik vakalar olması da anamnezde bu nedenlerin saklanabilmesine olanak tanımış olabilir. Ülkemiz koşullarında daha çok vertikal geçiş ve ev içi bulaş çoğunlukta görülmektedir. HBV enfeksiyonunun bizim ülkemiz gibi endemik olduğu yerlerde kişiler arasında horizontal bulaş, yakın temasla küçük deri sıyrıkları ve muköz membranlardan geçişiyle oluşabilir. Vücut sıvıları test edildiğinde HBsAg pozitifliği saptanmış ve semen ve tükürükte bu pozitiflik kanıtlanmıştır ancak buralardaki viral yük seruma göre 1.000 kez daha azdır (13). Çalışmaya alınan hastaların tahmini viral bulaş şekline ilişkin anamnezleri sorgulanmıştır. Hastaların \%10.1'inde anamnezde özellik saptanmamıştır. Tahmini bulaş yolları arasında \%68.3 ile illk sırada diş tedavisi öyküsü yer almaktadır. Bunu \%34.4 ile hastanede yatış, \%32.9 ile cerrahi girişim, \%19.3 ile kan transfüzyonu ve $\% 2.2$ ile şüpheli ilişki izlemektedir.

Çalışmaya alınan hastalarda aile üyelerinde hepatit B varlığı sorgulanmıştır ve aile üyeleri arasında en çok annelerde tespit edilmiştir. Bu da ülkemizde hepatit B'nin anneden vertikal geçiş oranının yüksekliğini göstermektedir. Anneden bebeğe perinatal HBV geçişinde en önemli faktörün HBeAg olduğu gösterilmiştir. HBeAg'in plesantayı geçebilmesine rağmen bulaş daha çok doğum sırasında veya sonradan oluşabilen deri ve mukoza sıyrıklarının enfekte maternal sıvilarla teması, vajinal kanaldan geçiş sırasında anne kanı ile temas, plesanta hasarı sonucu maternal dolaşımın fetal dolaşıma karışması gibi nedenlerle oluşur $(14,15)$. Türkiye gibi pek çok endemik ülkede vertikal bulaş HBV enfeksiyonunun ana kaynağıdır (16).

Aile üyeleri arasında kardeşlerdeki HBsAg pozitifliğine baktığımızda \%13.7'lik bir oran görülmektedir. Hastaların 112'sinin en az bir kardeşlerinde hepatit vardır. Kardeşlerinde hepatit olan hastaların büyük çoğunluğunun (\%77.7) annelerinde de hepatit mevcuttur. Bu durum kardeşler arasında hepatit B bulaşı olabileceği gibi yüksek olasılıkla anneden vertikal bulaşı gösterebilir. Çocuklar arasındaki horizontal geçişin kaynağı tam olarak bilinmemektedir. Ortamdaki eşyaların kontaminasyonunun bulaşmada etken olabileceği düşünülmektedir. Tükürüğün deri ve ağız yaraları ile teması, enfekte kişilerin daha önce ağzına temas etmiş gıdalar ile HBV enfeksiyonunun geliş̧ebildiği bildirilmiştir. Buna karşıllık enfekte tükürük ile horizontal bulaşın rolünü daha net ortaya koyacak çalışmalara gerek olsa da horizontal bulaşın muhtemel bir bulaş yolu olarak düşünülmesinde fayda vardır. HBV vücut dışında haftalarca yaşayabilmekte ve tıraş bıçağı, diş fırçası gibi cansız yüzeylerde bulunabilmektedir (17).

Hastaların 182'sinin (\%22.2) babalarında hepatit vardır. Babalarında hepatit olan hastaların büyük çoğunluğunun annelerinde hepatit B mevcut değildir. Bu da bilinenin aksine babadan hepatit B'nin bulaşabildiğini göstermektedir.

Erişkinler arasında yüksek riskli cinsel ilişki HBV enfeksiyonunun sık görülen nedenlerinden birisidir. Her ne kadar homoseksüel ilişki ile HBV enfeksiyonu geçişi daha çok olsa da heteroseksüel ilişki de HBV enfeksiyonunun en sık nedenlerindendir (18). Çalışmamızda hastaların 184'ünün (\%22.4) eşinde hepatit vardır. Bu oran cinsel yolla bulaşın bir göstergesi olabileceği gibi beklenenden düşük olması evlilik öncesi yapılan tarama ve HBsAg pozitif vakaların eşlerinin aşılamasına bağlanabilir.

Çalışmaya alınan hastalar evde ortak eşya kullanımı açısından değerlendirildiğinde \%83.2 ile aynı havluyu kullanma ilk sırada yer almakta, bunu \%79.3 ile aynı tıraş bıçağını, tırnak makasını kullanma ve \%69.8 ile aynı mutfak eşyasını kullanma izlemektedir. Çocuklar arasındaki bulaşı anlatırken bahsettiğimiz gibi horizontal bulaşta ortak kullanılan eşyaların kontaminasyonu etken olabilir. HBV virüsünün vücut dışında haftalarca yaşayabilmesi tıraş bıçağı, diş fırçası gibi eşyaların ortak kullanımı sonucu virüsü diğer aile bireylerine taşır. Yine enfekte kişilerin daha önce ağzına temas etmiş gıdalar sağlıklı bireyin deri ve ağız yaraları ile temas ettiğinde bulaşa neden olabilir.

Kan örneklerinde transfüzyon öncesi HBsAg'nin taranması 40 yıl önce başlamıştır. Bu taramalardaki ilerleme ile kan transfüzyonu ile geçiş günümüzde oldukça azalmıştır. Ama bu risk hiçbir zaman sıfır değildir. Hemodiyaliz, diş tedavisi, cerrahi girişim gibi diğer kanla geçişin olabileceği durumlar daha yaygındır. Bizim hastalarımızda tahmini bulaş yolları arasında \%68.3 ile ilk sırada diş tedavisi öyküsü yer almaktadır. Bunu \%34.4 ile hastanede yatış, \%32.9 ile cerrahi girişim, \%19.3 ile kan transfüzyonu izlemektedir. Kan transfüzyonu beklenildiği gibi en düşük orandadır. Ancak burada verdiğimiz rakamlar sadece hasta anamnezlerine dayandıııldığı için kesin bulaş yolu olarak değerlendirmemekteyiz.

Bizim çalışmamızda kliniğimiz hepatit B polikliniğinde takipli 820 hastanın aile bireyleri ve olası bulaş yolları değerlendirildi. Aile üyelerinde en fazla HBsAg prevalansı annelerde ve kardeşlerde, en düşük HBsAg prevalansı eşlerde ve babalarda izlendi. 
Okuryazar olmamak, geleneksel yöntemlerle ve ebe yardımı ile evde doğmuş olmak hepatit B bulaşması yönünden yüksek riskli görüldü.

Evde ortak eşya kullanımı açısından değerlendirildiğinde aynı havluyu kullanma ilk sırada yer almakta, bunu aynı tıraş bıçağını, tırnak makasını kullanma ile aynı mutfak eşyasını kullanma izlemektedir. Ancak aynı havluyu kullanmaktaki yüksek oran kullanan kişi sayısının fazlalığından kaynaklanmaktadır.

İnaktif HBV taşıyıcısı ve özellikle kronik aktif hepatitli indeks vakaların aile üyelerine bulaş riski çalışmamızda yüksek bulunmuştur.

\section{KAYNAKLAR}

1. Ott JJ, Stevens GA, Groeger J, Wiersma ST. Global epidemiology of hepatitis B virus infection: new estimates of age-specific HBsAg seroprevalence and endemicity. Vaccine 2012;30:2212-9.

2. Thomas D, Zoulim F. New challenges in viral hepatitis. Gut 2012;61:1- 5 .

3. Jonas MM. Hepatitis B and pregnancy: an underestimated issue. Liver International 2009;29:133-9.

4. FitzSimmons D, Francois G, De Carli G, et al. Hepatitis B virus, hepatitis $C$ virus and other blood-borne infections in healthcare workers: guidelines for prevention and management in industrialised countries. Occup Environ Med 2008;65:446-51.

5. Ni YH. Natural history of hepatitis B virus infection. Pediatric perspective. J Gastroenterol 2011;46:1-8.

6. Toy $M$, Önder FO, Wörmann $T$, et al. Age- and region- specific hepatitis B prevalence in Turkey estimated using generalized linear mixed models: a systematic review. BMC Infect Dis 2011;12:33749.

7. Demirpençe Ö, Tezcan SI, Değirmen E, et al. Batman Devlet Hastanesine başvuran kişilerde hepatit ve HIV serolojisinin sonuçları. Viral Hepatit Dergisi 2012;18:6-10.

8. Karabay O, Serin E, Tamer A, et al. Hepatitis B carriage and Brucella seroprevalence in urban and rural areas of Bolu province of Turkey: a prospective epidemiologic study. Turk J Gastroenterol 2004; 15:11-3.

9. Gürkan Y, Toyran A, Aksoy A, et al. Evaluation of HBsAg and anti-HDV seroprevalance of patients who admitted to Ankara Numune Training and Research Hospital between 2010 - 2013. Viral Hepat J 2013;19:148-51.
Dünya genelinde HBV prevalansı oldukça farklıdır. Bununla birlikte HBV aşılanmasının tüm dünyada uygulanıyor olması hastalığı prevalansın en yoğun olduğu ülkelerde bile azaltmaktadır. Ancak buna rağmen tüm dünyada yeni vakalar görülmektedir. HBV bulaş yollarının iyi bilinmemesi, her bölgede yeterli aşılamanın yapılamaması ve birçok vakanın enfekte olduklarının farkında olmaması bunun nedenidir. Bu hastalıktan toplumu korumak için hepatitler ve diğer kan yolu ile bulaşan hastalıklar konusunda tüm toplumun bilgi düzeyini arttırmaya yönelik çalışmalar yapılmalıdır. HBsAg pozitif bireylerin tüm aile fertleri aşılanmalıdır.

10. Dursun M, Ertem M, Yılmaz Ş, et al. Prevalance of hepatitis B infection in the southeastern region of Turkey: comparison of risk factors for HBV infection in rural and urban areas. J Infect Dis 2005;58:15-9.

11. Wasley A, Grytdal S, Gallagher K. Surveillance for Acute Viral Hepatitis-United States 2006. MMWR Morb Mortal Wkly Rep 2008;57:124.

12. Külah C, Cömert F, Özlü N, et al. Evaluation of serological markers, transaminase levels and HBV DNA in hepatitis B virus infections. Viral Hepatit Dergisi 2007;12:111-5.

13. Ott JJ, Stevens GA, Wiersma ST. The risk of perinatal hepatitis B virus transmission: hepatitis $B$ e antigen $(\mathrm{HBeAg})$ prevalence estimates for all World regions. BMC Infect Dis 2012;12:131.

14. Gönen I. Kırsal kesimde gebelerde HBV ve HCV sıklığı. Viral Hepatit Dergisi 2011;17:66-8.

15. Hui AY, Hung LCT, Tse PCH, et al. Transmission of hepatitis $B$ by 8 hepatitis research and treatment human bite- confirmation by detection of virus in saliva and full genome sequencing. J Clin Virol2005;33:254-6.

16. Lobato C, Tavares-Neto J, Rios-Leite M, et al. Intrafamilial prevalence of hepatitis $B$ virus in Western Brazilian Amazon region: epidemiologic and biomolecular study. J Gastroenterol Hepatol 2006;21:863-8

17. Inan N, Tabak F. Hepatitis B virus: Biology and life cycle. Viral Hepat J 2015;21:1-7.

18. Chang MH, Chen CJ, Lai MS, et al. Universal hepatitis B vaccination in Taiwan and incidence of hepatocelluler carcinoma in children. N Engl J Med 1997;336:1855-94. 